\title{
HAEMAGGLUTININS AND ADHESION OF ESCHERICHIA COLI TO HEp2 EPITHELIAL CELLS
}

\author{
Anne Tavendale and D. C. Old \\ Department of Medical Microbiology, University of Dundee Medical School, \\ Ninewells Hospital, Dundee DDI $9 S Y$
}

\begin{abstract}
Summary. Strains of Escherichia coli producing type-1 fimbriae, associated with mannose-sensitive haemagglutinin (MSHA), or three antigenically different kinds of 'MRE' fimbriae, associated with mannose-resistant and eluting haemagglutinins (MREHAs), adhered poorly to HEp2 epithelial cells in an in-vitro adhesion model previously used to demonstrate the importance of motility and type-1 fimbriae for the attachment of strains of Salmonella typhimurium to HEp2 cells. Strains of $E$. coli producing narrow-spectrum MREHA, agglutinating human erythrocytes only of 14 red-cell species tested, adhered well to HEp2 cells, particularly so when bacteria produced MSHA (and type-1 fimbriae) along with the narrow-spectrum 'man-only' MREHA. These findings are discussed with regard to recent observations suggesting that narrow-spectrum 'man-only' MREHA in E. coli may be associated with fine, fibrillar appendages $2-\mathrm{nm}$ wide.
\end{abstract}

\section{INTRODUCTION}

Among the different assay systems employed for measurement of bacterial adhesion, tissue-culture methods are considered useful in terms of their technical simplicity, ease of performance and high reproducibility (Vosbeck and Mett, 1983). Furthermore, tissue-culture assays have been used to demonstrate a correlation between in-vitro adhesion and bacterial pathogenicity in vivo (Bergman et al., 1981; Clausen and Christie, 1982).

In a previous study, we showed that the ability of strains of Salmonella typhimurium to adhere to HEp2 or HeLa epithelial cells was strongly associated with motility, production of type-1 fimbriae and an associated mannose-sensitive haemagglutinin, MSHA (Tavendale et al., 1983). From these studies, it was clear that a strong reaction in the epithelial-cell model in vitro did not reflect a property essential for infectivity of Salmonella spp. in vivo because many $\mathrm{MSHA}^{-}$strains of $S$. typhimurium were highly infective in animals (Tavendale et al., 1983).

Most strains ( $85 \%$ ) of Escherichia coli also produce MSHA which is associated with production of type-1 fimbriae, though these are antigenically distinct from the type-1 fimbriae of Salmonella spp. (Duguid and Old, 1980). Furthermore, c. 45\% of strains of $E$. coli produce a wide range of mannose-resistant and eluting haemagglutinins 
(MREHAs) (Duguid et al., 1955 and 1979; Old, 1985). Some of these MREHAs are associated with the presence of 'MRE' fimbriae of diverse antigenicity (Duguid and Old, 1980); others, the group-III narrow-spectrum MREHAs (see Duguid et al., 1955; Duguid, 1964), are apparently non-fimbrial (Duguid et al., 1955 and 1979).

The purpose of the present study was to investigate the role of MSHA, and its associated type-1 fimbriae, and the fimbrial and non-fimbrial MREHAs of strains of $E$. coli of different HA phenotypes in adhesion to HEp2 epithelial cells in vitro, a system that has found much recent favour as an in-vitro model of value in reflecting pathogenicity of strains of $E$. coli.

\section{MATERIALS AND METHODS}

Bacteria. Strains of $E$. coli were from the collection of Professor J. P. Duguid. The sources, serotypes and the MS and MRE haemagglutinins produced by the nine strains of $E$. coli tested in adhesion tests are listed in table I. S. typhimurium strain S6354, a motile type-1 fimbriate transductant of the FIRN strain of $S$. typhimurium S635, derived as described elsewhere (Old and Duguid, 1971 and 1979), was included for comparative purposes (see Tavendale et al., 1983).

Media. The preparation of nutrient broth, brain heart infusion broth and nutrient agar has been described in detail (Tavendale et al., 1983). Phosphate-buffered broth and agar $(p \mathrm{H} \mathrm{7.0)}$ were, respectively, nutrient broth and nutrient agar with $\mathrm{KH}_{2} \mathrm{PO}_{4} 0 \cdot 36 \%$ w/v and $\mathrm{Na}_{2} \mathrm{HPO}_{4}$ $0.64 \% \mathrm{w} / \mathrm{v}$.

Bacterial culture methods. Bacteria were screened for production of MSHA and MREHA by previously described methods (Duguid et al., 1979; Old, 1985).

For tests of adhesion to HEp2 cells, bacteria were grown in broth or on agar. For tests with broth-grown cultures, strains were grown as follows: (i) S. typhimurium strain S6354 and the five strains of $E$. coli listed in table II were first taken through four, serial, 48-h cultures in 10-ml volumes of nutrient broth in tubes incubated at $37^{\circ} \mathrm{C}$. Thereafter, a fifth subculture was made in brain heart infusion broth $(20 \mathrm{ml})$ in a thin layer $(10 \mathrm{~mm})$ in a conical flask incubated statically in air for $24 \mathrm{~h}$ at $37^{\circ} \mathrm{C}$. This fifth, brain-heart-broth culture was used in adhesion tests for the strains listed in table II. Under these conditions, genotypically $\mathrm{MSHA}^{+}$strains formed much MSHA and genotypically MREHA ${ }^{+}$strains of $E$. coli formed little, or no, MREHA (of patterns 1,3 and 4); (ii) the four strains listed in table III were grown similarly except that phosphate-buffered broth was used for all subcultures, including the fifth which was used in adhesion tests. Under these conditions, genotypically $\mathrm{MSHA}^{+}$strains formed much MSHA and genotypically

TABLE I

Strains of E. coli used in adhesion tests

\begin{tabular}{|c|c|c|c|c|c|}
\hline \multirow[b]{2}{*}{$\begin{array}{c}\text { Strain } \\
\text { no. }\end{array}$} & \multirow[b]{2}{*}{ Source } & \multirow[b]{2}{*}{ Serotype } & \multirow[b]{2}{*}{ Motility } & \multicolumn{2}{|c|}{ Haemagglutinins } \\
\hline & & & & MSHA & $\begin{array}{l}\text { MREHA } \\
\text { (pattern)* }\end{array}$ \\
\hline C315 & Urine & 05:K4:H4 & - & - & - \\
\hline A 128 & Faeces & 0128:K67:H2 & + & + & - \\
\hline G14 & Urine & $02: \mathrm{K} ?: \mathrm{H} ?$ & + & - & $+(1)$ \\
\hline G34 & Urine & 06:K?:H- & - & - & $+(3)$ \\
\hline A92 & Urine & $02: \mathrm{K} ?: \mathrm{H} ?$ & + & - & $+(4)$ \\
\hline A224 & Urine & 021:K 7:H4 & + & - & $+(9)$ \\
\hline $\mathrm{C} 5$ & Faeces & 025:K?:H6 & + & - & $+(9)$ \\
\hline Al11 & Faeces & $021: \mathrm{K} ?: \mathrm{H} 4$ & + & + & $+(9)$ \\
\hline N9021 & Unknown & 021:K20:H- & - & + & $+(9)$ \\
\hline
\end{tabular}

* For details of erythrocyte species agglutinated by MREHA+ strains of $E$. coli of patterns 1, 3, 4 and 9 , see Duguid et al. (1979).

$?=$ antigen not known or not designated. 
TABLE II

MSHA, MREHA and adhesion to HEp2 cells of broth- and agar-grown cultures of E. coli*

\begin{tabular}{|c|c|c|c|c|c|c|c|}
\hline \multirow{3}{*}{$\begin{array}{c}\text { Strain } \\
\text { no. }\end{array}$} & \multirow{3}{*}{$\begin{array}{l}\text { Growth } \\
\text { medium } \dagger\end{array}$} & \multirow{3}{*}{$\begin{array}{c}\text { Motile } \\
\text { bacteria } \\
(\%) \text { in } \\
\text { culture }\end{array}$} & \multirow{2}{*}{\multicolumn{2}{|c|}{$\begin{array}{l}\text { Titre of } \\
\text { bacteria }\end{array}$}} & \multicolumn{3}{|c|}{$\begin{array}{c}\text { Number of attached bacteria/HEp2 } \\
\text { cell in test that was }\end{array}$} \\
\hline & & & & & \multicolumn{2}{|c|}{ static overlay } & \multirow{2}{*}{$\begin{array}{l}\text { stirred underlay } \\
-\alpha \mathrm{MM}\end{array}$} \\
\hline & & & MSHA & MRHA & $-\alpha \mathrm{MM}$ & $+\alpha \mathrm{MM}$ & \\
\hline *S6354 & Broth & 85 & 2700 & 0 & $\geqslant 50$ & $0 \cdot 5$ & $24 \cdot 7$ \\
\hline A128 & Broth & 40 & 3700 & 0 & $1 \cdot 3$ & $0 \cdot 1$ & $0 \cdot 1$ \\
\hline A128 & Agar & $<1$ & 80 & 0 & $0 \cdot 3$ & $0 \cdot 1$ & $<0.1$ \\
\hline G14 & Broth & 50 & 0 & 0 & 0.4 & $0 \cdot 3$ & $<0.1$ \\
\hline G14 & Agar & $<1$ & 0 & 90 & 0.6 & 0.4 & 0.3 \\
\hline G34 & Broth & 0 & 0 & 0 & 0.2 & $0 \cdot 2$ & $<0.1$ \\
\hline G34 & Agar & 0 & 0 & 45 & $0 . \overline{4}$ & $0 . \overline{6}$ & $0 \cdot 3$ \\
\hline A92 & Broth & 60 & 0 & 110 & 1.0 & 0.7 & $0 \cdot 1$ \\
\hline A92 & Agar & $<1$ & 0 & 340 & $1 \cdot 1$ & $0 \cdot 8$ & 0.5 \\
\hline C315 & Broth & 0 & 0 & 0 & 0.2 & $0 \cdot 2$ & $<0.1$ \\
\hline C 315 & Agar & 0 & 0 & 0 & $0 \cdot 6$ & $1 \cdot 1$ & 0.3 \\
\hline
\end{tabular}

*S. typhimurium strain S6354 included for comparison.

$\dagger$ Broth was nutrient broth; agar was phosphate-buffered nutrient agar ( $p \mathbf{H} 7 \cdot 0)$.

TABLE III

Narrow-spectrum MREHA* and adhesion to HEp2 cells of broth-and agar-grown cultures of $E$. coli

\begin{tabular}{|c|c|c|c|c|c|c|c|}
\hline \multirow{3}{*}{$\begin{array}{l}\text { Strain } \\
\text { no. }\end{array}$} & \multirow{3}{*}{$\begin{array}{l}\text { Phosphate- } \\
\text { buffered } \\
\text { growth } \\
\text { medium } \\
(p \mathrm{H} \mathrm{7 \cdot 0)}\end{array}$} & \multirow{3}{*}{$\begin{array}{l}\text { Motile } \\
\text { bacteria } \\
(1 \%) \text { in } \\
\text { culture }\end{array}$} & \multirow{2}{*}{\multicolumn{2}{|c|}{$\begin{array}{l}\text { Titre of } \\
\text { bacteria }\end{array}$}} & \multicolumn{3}{|c|}{$\begin{array}{l}\text { Number of attached bacteria/HEp2 } \\
\text { cell in test that was }\end{array}$} \\
\hline & & & & & \multicolumn{2}{|c|}{ static overlay } & \multirow{2}{*}{$\begin{array}{c}\text { stirred underlay } \\
-\alpha \mathrm{MM}\end{array}$} \\
\hline & & & MSHA & MRHA & $-\alpha \mathrm{MM}$ & $+\alpha \mathrm{MM}$ & \\
\hline A224 & Broth & $5-10$ & 0 & 400 & $3 \cdot 7$ & $3 \cdot 3$ & $0 \cdot 3$ \\
\hline A224 & Agar & $<1$ & 0 & 160 & $3 \cdot 6$ & $3 \cdot 5$ & 0.6 \\
\hline C5 & Broth & $1-5$ & 0 & 250 & $5 \cdot 7$ & $6 \cdot 7$ & 0.7 \\
\hline C5 & Agar & $<1$ & 0 & 4000 & $5 \cdot 4$ & $4 \cdot 4$ & $1 \cdot 1$ \\
\hline A111 & Broth & $10-20$ & 500 & 60 & $29 \cdot 5$ & $28 \cdot 8$ & 0.5 \\
\hline Al11 & Broth $\dagger$ & 0 & 0 & 0 & 0.8 & 0.9 & \\
\hline A111 & Agar & $<1$ & 0 & 2300 & $2 \cdot 1$ & $2 \cdot 2$ & $0 \cdot 4$ \\
\hline N9021 & Broth & 0 & 3030 & 200 & $12 \cdot 6$ & $12 \cdot 0$ & 1.6 \\
\hline N902i & Broth $\dagger$ & 0 & 0 & 0 & 0.7 & 0.4 & \\
\hline N9021 & Agar & 0 & 0 & 1700 & $3 \cdot 3$ & $4 \cdot 2$ & $0 \cdot 6$ \\
\hline
\end{tabular}

* These four strains of $E$. coli belong to MREHA-group 9 of Duguid et al. (1979), i.e., they give mannoseresistant haemagglutination of human erythrocytes only of 14 species tested.

† Grown in phosphate-buffered broth at $18^{\circ} \mathrm{C}$ for $48 \mathrm{~h}$.

$\ldots=$ not tested.

$\mathrm{MREHA}^{+}$strains also formed MREHA (of pattern 9). In a few experiments, strains were grown, from an inoculum taken from a nutrient-agar stock culture, in phosphate-buffered broth for $48 \mathrm{~h}$ at $18^{\circ} \mathrm{C}$ to inhibit production of MREHA.

For adhesion tests with agar-grown cultures, all nine strains of $E$. coli were grown on plates of phosphate-buffered agar seeded confluently with material from a stock culture and incubated in air for $24 \mathrm{~h}$ at $37^{\circ} \mathrm{C}$.

Erythrocytes and haemagglutination tests. The preparation of erythrocytes of fowl, guinea pig, horse, man (group O), ox, pig and sheep was as before (Duguid et al., 1979). Rocked-tile tests followed the method of Duguid et al. (1966). MSHA and MREHA titres are expressed as 
the haemagglutination power (HP) estimated with the most sensitive species of erythrocyte for each of the different haemagglutinins (see Old, 1972; Duguid et al., 1979). Values of 1 and 1000, for example, indicated that the smallest concentration of bacteria that gave visible haemagglutination in the tests were, respectively, $10^{11}$ and $10^{8} / \mathrm{ml}$. A value of 0 indicated the absence of visible MSHA or MREHA activities in tests with $10^{11} / \mathrm{ml}$ of broth-grown or $5 \times 10^{11} / \mathrm{ml}$ of agar-grown bacteria (Tavendale et al., 1983).

Motility. The approximate proportion of motile bacteria was assessed in a wet film of the same bacterial suspension as that used for adhesion tests.

Maintenance and growth of HEp2 cells. The cells were obtained from Flow Laboratories, Irvine, Scotland. Their maintenance followed the detailed procedures described by Tavendale $e t$ al. (1983).

Cell adhesion tests. The fifth bacterial subculture made in brain heart infusion broth (strains in table II) or in phosphate-buffered broth (strains in table III) or the bacterial suspension from phosphate-buffered agar (all strains) was diluted (c. 10 or 50 fold) to a concentration of $1 \times 10^{9}$ bacteria/ml in Eagle's Minimal Essential Medium (Gibco Europe Ltd, Paisley, Scotland) supplemented with fetal bovine serum $0.5 \% \mathrm{w} / \mathrm{v}$, glutamine 20mM and HEPES buffer $(p \mathrm{H} 7 \cdot 3)$ (Gibco) $2 \% \mathrm{v} / \mathrm{v}$. Some tests were made with suspensions containing $\alpha$-methylmannoside $(\alpha \mathrm{MM})$ $0 \cdot 2 \% \mathrm{w} / \mathrm{v}$.

Two kinds of adhesion test were made in parallel with the same preparations of bacteria and cells: (i) static overlay test in the absence and presence of $\alpha \mathrm{MM}$ according to the detailed methods of Tavendale et al. (1983); (ii) stirred underlay test in a device originally recommended to us by $\mathrm{Dr}$ J. S. Burnham (for full details, see Tavendale et al., 1983), in the absence of $\alpha \mathrm{MM}$ and constantly stirred under the monolayer by a magnet $(125 \mathrm{rpm})$.

The incubation period $(30 \mathrm{~min})$ and the washing and staining procedures followed those described by Tavendale et al. (1983). The numbers of bacteria attached per HEp2 cell were estimated from the count of $c$. 200 cells (or in the case of larger counts, 50 or 100 cells) and the percentage of HEp2 cells showing adherent bacteria was also noted.

\section{RESULTS}

When bacteria from nutrient-broth cultures of $S$. typhimurium strain S6354, motile and rich in MSHA, were tested in the static overlay test in the absence of $\alpha \mathrm{MM}$, all HEp2 cells in the monolayer showed adherent bacteria in large numbers (50-100/ epithelial cell); however, in the presence of $\alpha \mathrm{MM}$ there were fewer HEp2 cells $(37 \%)$ with adherent bacteria and then in small numbers only ( $<1 /$ epithelial cell) suggesting that the adherence of strain S6354 to HEp2 cells was related to MSHA (table II).

Though E. coli strain A128, like strain S6354, was genotypically $\mathrm{MSHA}^{+}$ MREHA $^{-}$, its broth-grown bacteria, motile and MSHA-rich, tested similarly in the static overlay test adhered to only $55 \%$ of the HEp2 cells and in very small numbers ( $<1$ /epithelial cell). Nevertheless, even these low levels of adhesion were essentially abolished in tests made in the presence of $\alpha \mathrm{MM}$ (table II).

None of the $E$. coli strains G14, G34 and A92 produced MSHA though each formed a different kind of MREHA. Strain G14 gave mannose-resistant haemagglutination of the red cells of man, pig and sheep (pattern 1 of Duguid et al., 1979) and each of the strains G34 and A92 (patterns 3 and 4, respectively) gave mannose-resistant haemagglutination of the red cells of fowl, guinea pig, horse, man, ox, pig and sheep, definition of their patterns requiring the use of further erythrocyte species (Duguid et al., 1979). Grown on phosphate-buffered agar at $37^{\circ} \mathrm{C}$, their production of MREHA was enhanced. When these MREHA-rich bacteria were tested in the static overlay test, they adhered to only $45 \%$ of the observed HEp 2 cells whereas bacteria from brothgrown cultures, either MREHA-poor (strain A92) or MREHA-negative (strains G14 
and G34), adhered to even fewer $(30 \%)$ of the HEp2 cells. The mean number of adherent bacteria (c. $0.5-0.6 /$ epithelial cell) was equally low regardless of the method of culture used, the MREHA status of the cultures and the presence or absence of $\alpha M M$ (table II). The lack of effect of motility was perhaps best seen with strain A92, the most adhesive of the $\mathrm{MREHA}^{+}$strains, for its motile $\mathrm{MREHA}^{+}$bacteria from broth cultures were as poorly adhesive as non-motile MREHA ${ }^{+}$bacteria from agar cultures, judged either by the percentage of HEp 2 cells $(51-57 \%)$ showing adherent bacteria or by the numbers of bacteria adhering ( $<1 /$ epithelial cell) (table II).

The non-motile strain C315 produced neither MSHA nor MREHA yet bacteria from its broth- or agar-grown cultures were not markedly less adhesive than the $\mathrm{MSHA}^{+}$or MREHA ${ }^{+}$strains of $E$. coli (table II).

In the more stringent conditions of the stirred underlay test made in the absence of $\alpha \mathrm{MM}$ with motile, MSHA-rich bacteria of strain S6354, all HEp2 cells showed large numbers of adherent bacteria (c. 25/epithelial cell) and confirmed that strain S6354 behaved as previously described (Tavendale et al., 1983). However, in similar tests made with $E$. coli strains, bacteria from agar-grown cultures of strain A92 adhered to more $(36 \%)$ of the HEp2 cells than did those from suspensions of other strains, but neither MSHA-rich bacteria from broth- or agar-grown suspensions of these five strains of $E$. coli adhered in large numbers (mean $<0 \cdot 2$; range $<0 \cdot 1-0 \cdot 5 /$ epithelial cell) (table II).

Whereas the MREHAs of patterns 1, 3 and 4 are fimbriae-associated, that associated with pattern 9 (mannose-resistant haemagglutination of human erythrocytes only) is considered to be non-fimbrial (Duguid et al., 1979). Grown at $37^{\circ} \mathrm{C}$ in phosphate-buffered broth or agar, cultures of the four strains of $E$. coli listed in table III were $\mathrm{MREHA}^{+}$. In static overlay tests, bacteria from buffered-broth and bufferedagar cultures $\left(37^{\circ} \mathrm{C}\right)$ adhered in a mannose-independent manner to, respectively, $97 \%$ and $85 \%$ of the HEp 2 cells. Furthermore, with strains A224 and C 5 the mean numbers of adherent bacteria/HEp2 cells were similar whether tests were made with agar or broth cultures (table III). In tests with genotypically MSHA $^{+}$strains, however, the numbers of bacteria adhering to HEp2 cells were much greater with suspensions from buffered-broth cultures of strains A111 (30/epithelial cell) and N9021 (13/epithelial cell) than with suspensions from buffered-agar cultures (respectively, 2 and $3 /$ epithelial cell). Though the major difference in haemagglutinating activities between bufferedbroth and -agar cultures of these strains is that the former are MSHA-rich, the high level of adhesion shown by bacteria from broth-grown cultures was not inhibited by $\alpha \mathrm{MM}$ (table III). When MREHA production was suppressed by growing strains A111 and N9021 in buffered broth at $18^{\circ} \mathrm{C}$, the resultant bacteria, MSHA- and MREHAnegative and non-motile, were poorly adherent $(<1 /$ epithelial cell, table III).

In stirred underlay tests with bacteria from suspensions of these four narrowspectrum MREHA ${ }^{+}$strains of E. coli grown on buffered media at $37^{\circ} \mathrm{C}$, adhesion was uniformly poor (table III). Thus, few HEp2 cells (18-62\%) showed adherent bacteria and the numbers of bacteria adhering per epithelial cell were low $(\leqslant 1)$ (table III).

\section{Discussion}

Many enterobacteria form type-1 fimbriae which mediate mannose-sensitive adhesion to a wide range of eukaryotic cells (Duguid and Old, 1980). Though classified 
in the same general mannose-sensitive group, the type-1 fimbriae of different species and genera are not identical. For example, the type-1 fimbriae of E. coli and Salmonella serotypes, including $S$. typhimurium, are different in their major fimbrial antigens (Duguid and Campbell, 1969; Nowotarska and Mulczyk, 1977) and in their chemical composition (Korhonen et al., 1980). Furthermore, recent sugar-inhibition studies have revealed that the type-1 fimbriae of $E$. coli and Salmonella serotypes exhibit differences in sugar specificities (Firon et al., 1984). The combining sites of the type-1 fimbriae of $E$. coli are elongated (at least a trisaccharide) and contain a hydrophobic region whereas those of salmonellae, including $S$. typhimurium, are considerably different and are devoid of a hydrophobic region. These observations suggest that there are important differences in the structure of the 'mannose-sensitive' receptors of the type-1 fimbriae of E. coli and S. typhimurium (Firon et al., 1984).

Another likely difference emerges from the present study. Thus, whereas motile, MSHA-rich (type-1 fimbriate) S. typhimurium adhered to HEp2 cells in large numbers in both 'right-side-up' and 'upside-down' tests, motile MSHA-rich (type-1 fimbriate) $E$. coli were poorly adherent and at low levels which previously we had considered insignificant and likely to be at the limits of sensitivity of this particular in-vitro adhesion model (Tavendale et al., 1983). If, as suggested by Firon et al. (1984), there are subtle differences in the receptors recognised by the type- 1 fimbriae of $E$. coli and $S$. typhimurium, the present observations probably reflect corresponding differences in the availability of appropriate receptors on HEp2 cells for E. coli and S. typhimurium.

Some pyelonephritogenic strains of $E$. coli form special P-fimbriae, so called because they recognise specifically human erythrocytes of common $\mathbf{P}$ blood-group types but not those of the rare $\overline{\mathrm{p}}$ type (Källenius et $a l ., 1980 a$ and $b$ ). P-fimbriate strains of $E$. coli may be recognised by agglutination of latex particles coated with P-receptor substance (Svenson et al., 1982) or by inhibition of haemagglutination of human erythrocytes by hydatid-cyst fluid (Parry et al., 1984). By these criteria, E. coli strain G14 forms P-fimbriae (Dr P. B. Crichton, personal communication). Our finding that strain G14 adhered poorly to HEp2 cells in our in-vitro model is in agreement with similar findings for other P-fimbriate strains in tests with other tissue-culture lines (Jann et al., 1981).

Although urinary strains of E. coli G34 and A92, like strain G14, did not form type1 fimbriae, they produced MREHAs of patterns 3 and 4 (Duguid et al., 1979) and their $\mathrm{MREHA}^{+}$cultures agglutinated a wide range of erythrocyte species including human $\overline{\mathrm{p}}$ cells. Strains G34 and A92 form MRE fimbriae antigenically distinct from each other and from the P-fimbriae of strain G14 (Clegg, 1978), but were no more efficient in adhesion to HEp2 cells than strain G14. Thus, regardless of whether strains of E. coli produced type- 1 fimbriae or one of three different antigenic types of MRE fimbriae, none adhered as efficiently to HEp2 cells in this model as the type-1 fimbriate strain $S$. typhimurium S6354. It is clear, therefore, from this and other studies (Vosbeck and Mett, 1983) that there is no correlation among urinary strains of $E$. coli between production of MR adhesin and ability to adhere to different tissue-culture lines, though occasional MREHA ${ }^{+}$strains of urinary origin apparently adhere well to some kinds of tissue-culture cells (Vosbeck and Huber, 1982).

About $10 \%$ of $\mathrm{MREHA}^{+}$, urinary strains of $E$. coli recognise receptors other than those recognised by P-fimbriate strains (Väisänen et al., 1981; Old, 1985). Though most strains of $E$. coli that produce MREHAs form antigenically different kinds of MRE 
fimbriae (Clegg, 1978), some strains produce non-fimbrial MREHAs (i.e., group III strains of Duguid et al., 1955). One such non-fimbrial MREHA is that responsible for agglutination of human erythrocytes only of 14 red-cell species tested (Duguid et al., 1955). Previous studies have indicated that the narrow-spectrum 'man only' MREHAs produced by the strains of $E$. coli used in this study were not associated with typical fimbrial structures (Duguid et al., 1955 and 1979; Ip et al., 1981). Similar mannoseresistant adhesins agglutinating human erythrocytes only have been described on both urinary and faecal strains of $E$. coli and shown to be associated with non-fimbrial hydrophobic proteins with subunit mol.wts in the range 14000-16000 (LabigneRoussel et al., 1984; Williams et al., 1984). Furthermore, the latter adhesin present on two strains of $E$. coli isolated from infants with severe dysentery was responsible for adherence to, and penetration of, HEp2 and HeLa cells (Knutton et al., 1984).

Two of the strains (A224 and C5) examined by us were among those recently studied in some detail by Ørskov et al. (1985) who also demonstrated the involvement of a cell-bound protein (subunit mol. wt of 14400) that they described as forming a 'protein capsule'. Both Knutton et al. (1984) and Ørskov et al. (1985) observed on occasional cells in some MREHA+ cultures the presence of fine, flexible fibrils of $c$. 2 $\mathrm{nm}$ diameter and the latter authors commented upon the apparent unsuitability of some kinds of negative stains for the demonstration of these fine fibrils which, when present, were resolved only with difficulty.

Thus, it may be that the 'man only' MREHA is associated with these delicate fibrils which may mediate attachment to epithelial cells. It is not clear, however, why the presence of type-1 fimbriae should so have enhanced the adhesiveness of some of our $\mathrm{MREHA}^{+}$(narrow-spectrum) strains. That stimulatory effect was mannose-insensitive suggesting that the type-1 fimbriae were acting non-specifically, perhaps, for example, by inducing formation of bacterial aggregates in a manner similar to that noted when the frequency of transfer of colI among strains of Shigella flexneri was enhanced by type-1 fimbriae themselves not essential for conjugation (Mulczyk and Duguid, 1966).

It is clear that results from this kind of in-vitro adhesion study should be interpreted with care and attempts should be made to assess the contributions made to adhesiveness by different kinds of bacterial surface structures. This is particularly true when it is recalled that many strains of $E$. coli form multiple adhesins (Duguid and Old, 1980; Ørskov and Ørskov, 1983).

We thank Professor J. P. Duguid for the gift of strains and information about them.

\section{REFERENCES}

Bergman M J, Updike W S, Wood S J, Brown S E, Guerrant R L 1981 Attachment factors among enterotoxigenic Escherichia coli from patients with acute diarrhea from diverse geographic areas. Infection and Immunity 32:881-888.

Clausen C R, Christie D L 1982 Chronic diarrhea in infants caused by adherent enteropathogenic Escherichia coli. Journal of Pediatrics 100: 358-361.

Clegg S 1978 The adhesive and antigenic properties of enterobacterial haemagglutinins. $\mathrm{Ph} \mathrm{D}$ thesis, University of Dundee.

Duguid J P 1964 Functional anatomy of Escherichia coli with special reference to enteropathogenic E. coli. Revista Latino-americana de Microbiologia 7, Supp 13-14:1-16.

Duguid J P, Campbell I 1969 Antigens of the type-1 fimbriae of salmonellae and other enterobacteria. Journal of Medical Microbiology 2:535-553. 
Duguid J P, Old D C 1980 Adhesive properties of Enterobacteriaceae. In: Beachey E H (ed) Bacterial adherence (Receptors and recognition, series B, vol 6.) Chapman and Hall, London, pp 185-217.

Duguid J P, Anderson E S, Campbell I 1966 Fimbriae and adhesive properties in salmonellae. Journal of Pathology and Bacteriology 92: 107-138.

Duguid J P, Clegg S, Wilson M I 1979 The fimbrial and non-fimbrial haemagglutinins of Escherichia coli. Journal of Medical Microbiology 12:213-227.

Duguid J P, Smith I W, Dempster G, Edmunds P N 1955 Non-flagellar filamentous appendages ("fimbriae") and haemagglutinating activity in Bacterium coli. Journal of Pathology and Bacteriology 70:335-348.

Firon N, Ofek I, Sharon N 1984 Carbohydrate-binding sites of the mannose-specific fimbrial lectins of enterobacteria. Infection and Immunity 43:1088-1090.

Ip S M, Crichton P B, Old D C, Duguid J P 1981 Mannose-resistant and eluting haemagglutinins and fimbriae in Escherichia coli. Journal of Medical Microbiology 14:223-226.

Jann K, Schmidt G, Blumenstock E, Vosbeck K 1981 Escherichia coli adhesion to Saccharomyces cerevisiae and mammalian cells: role of piliation and surface hydrophobicity. Infection and Immunity 32:484-489.

Källenius G, Möllby R, Svenson S B, Winberg J, Hultberg H 1980a Identification of a carbohydrate receptor recognised by uropathogenic Escherichia coli. Infection Supp 3:288293.

Källenius G, Möllby R, Svenson S B, Winberg J, Lundblad A, Svensson S, Cedergren B $1980 b$ The $\mathrm{P}^{\mathrm{k}}$ antigen as receptor for the haemagglutinin of pyelonephritic Escherichia coli. FEMS Microbiology Letters 7:297-302.

Knutton S, Williams P H, Lloyd D R, Candy D C A, McNeish A S 1984 Ultra-structural study of adherence to and penetration of cultured cells by two invasive Escherichia coli strains isolated from infants with enteritis. Infection and Immunity 44:599-608.

Korhonen T K, Lounatmaa K, Ranta H, Kuusi N 1980 Characterization of type-1 pili of Salmonella typhimurium LT2. Journal of Bacteriology 144:800-805.

Labigne-Roussel A F, Lark D, Schoolnik G, Falkow S 1984 Cloning and expression of an afimbrial adhesin (AFA-I) responsible for P blood group-independent, mannose-resistant hemagglutination from a pyelonephritic Escherichia coli strain. Infection and Immunity 46: 251-259.

Mulczyk M, Duguid J P 1966 Influence of the state of fimbriation on transmission of the colicinogenic factor coll between strains of Shigella flexneri. Journal of General Microbiology 45:459-477.

Nowotarska M, Mulczyk M 1977 Serologic relationship of fimbriae among Enterobacteriaceae. Archivum Immunologiae et Therapiae Experimentalis 25:7-16.

Old D C 1972 Inhibition of the interaction between fimbrial haemagglutinins and erythrocytes by D-mannose and other carbohydrates. Journal of General Microbiology 71:149-157.

Old D C, 1985 Haemagglutination methods in the study of Escherichia coli. In: Sussman M (ed) The virulence of Escherichia coli. Academic Press, London, pp 287-313.

Old D C, Duguid J P 1971 Selection of fimbriate transductants of Salmonella typhimurium dependent on motility. Journal of Bacteriology 107:655-658.

Old D C, Duguid J P 1979 Transduction of fimbriation demonstrating common ancestry in FIRN strains of Salmonella typhimurium. Journal of General Microbiology 112:251-259.

Ørskov I, Ørskov F 1983 Serology of Escherichia coli fimbriae. Progress in Allergy 33:80-105.

Ørskov I, Birch-Andersen A, Duguid J P, Stenderup J, Ørskov F 1985 An adhesive protein capsule of Escherichia coli. Infection and Immunity 47:191-200.

Parry S H, Rooke D M, Sussman M 1984 Analysis of mannose-resistant adhesins of Escherichia coli by a naturally occurring glycoprotein receptor analogue. Journal of Microbiological Methods 2:323-331.

Svenson S B, Källenius G, Möllby R, Hultberg H, Winberg J 1982 Rapid identification of Pfimbriated Escherichia coli by a receptor specific particle agglutination test. Infection 10: 209-214.

Tavendale, A, Jardine C K H, Old D C, Duguid J P 1983 Haemagglutinins and adhesion of Salmonella typhimurium to HEp2 and HeLa cells. Journal of Medical Microbiology 16:371380. 
Väisänen V, Tallgren L G, Makela P H, Källenius G, Hultberg H, Elo J, Siitonen A, Svanborg Edén C, Svenson S B, Korhonen T 1981 Mannose-resistant haemagglutination and P antigen recognition are characteristic of Escherichia coli causing primary pyelonephritis. Lancet 2: 1366-1396.

Vosbeck K, Huber U 1982 An assay for measuring specific adhesion of an Escherichia coli strain to tissue culture cells. European Journal of Clinical Microbiology 1:22-28.

Vosbeck K, Mett H 1983 Bacterial adhesion: influence of drugs. In: Easmon C S F et al. (eds) Medical microbiology, vol 3. Academic Press, London, pp 21-62.

Williams P H, Knutton S, Brown M G M, Candy D C A, McNeish A S 1984 Characterization of nonfimbrial mannose-resistant protein hemagglutinins of two Escherichia coli strains isolated from infants with enteritis. Infection and Immunity 44:592-598. 